\title{
Effects of Forage Particle Size and Grain Fermentability in Midlactation Cows. II. Ruminal pH and Chewing Activity
}

\author{
K. M. Krause ${ }^{\star}$, D. K. Combs ${ }^{\star}$, and K. A. Beauchemin† \\ ${ }^{*}$ Department of Dairy Science, \\ University of Wisconsin, Madison 53706 \\ †Research Centre, Agriculture and Agri-Food Canada, Lethbridge, AB, Canada T1J 4B1
}

\begin{abstract}
Our study investigated the effects of, and interactions between, level of dietary ruminally fermentable carbohydrate (RFC) and forage particle size on rumen $\mathrm{pH}$ and chewing activity for dairy cows fed one level of dietary NDF. Also, correlations between intake, production, chewing, and ruminal $\mathrm{pH}$ parameters were investigated. Eight cows (61 days in milk) were assigned to four treatments in a double $4 \times 4$ Latin square. Treatments were arranged in a $2 \times 2$ factorial design; finely chopped alfalfa silage (FS) and coarse alfalfa silage (CS) were combined with concentrates based on either dry, cracked-shelled corn (DC; low RFC) or ground, highmoisture corn (HMC; high RFC). Diets were fed ad libitum as a total mixed rations with a concentrate:forage ratio of $60: 40$. Diets averaged $18.7 \%$ crude protein, $24.0 \%$ neutral detergent fiber, $18.3 \%$, acid detergent fiber and $27.4 \%$ starch on a DM basis. Mean particle size of the four diets were $6.3,2.8,6.0$, and $3.0 \mathrm{~mm}$ for DCCS, DCFS, HMCCS, and HMCFS, respectively. Decreasing forage particle size decreased ruminal $\mathrm{pH}$ from 6.02 to 5.81, and increasing level of RFC decreased $\mathrm{pH}$ from 5.99 to 5.85 . Minimum daily ruminal $\mathrm{pH}$ decreased from 5.66 to 5.47 when level of RFC was increased, and decreased from 5.65 to 5.48 when forage particle size decreased. Time below $\mathrm{pH} 5.8$ per day increased from $7.4 \mathrm{~h}$ to $10.8 \mathrm{~h}$ when level of RFC increased, and increased from $6.4 \mathrm{~h}$ to $11.8 \mathrm{~h}$ when forage particle size was decreased. Area below 5.8 showed the same relationship with RFC and forage particle size. Also, forage particle size affected the postprandial $\mathrm{pH}$ pattern. Cows spent more time eating when fed CS compared with FS (274 vs. $237 \mathrm{~min} / \mathrm{d}$ ), and time spent eating decreased when level of RFC was increased (271 vs. $241 \mathrm{~min} / \mathrm{d}$ ). Decreasing forage particle size decreased time spent ruminating (485 vs. $320 \mathrm{~min} / \mathrm{d}$ ), rumination periods (15.3 vs. 11.7 ), and duration of rumi-
\end{abstract}

Received September 12, 2001.

Accepted February 4, 2002.

Corresponding author: D. K. Combs; e-mail: dkcombs@facstaff. wisc.edu. nation periods ( $29 \mathrm{vs} .26 \mathrm{~min}$ ). Increasing level of RFC increased time spent ruminating per $\mathrm{kg}$ NDF intake (68.5 vs. $79.5 \mathrm{~min} / \mathrm{kg}$ ). Milk fat percentage was correlated to mean ruminal $\mathrm{pH}(\mathrm{r}=0.41)$, time spent below $\mathrm{pH} 5.8(\mathrm{r}=-0.55)$, and area below $5.8(\mathrm{r}=-0.57)$, but not to intake or chewing variables. DMI of particles retained on a screen equivalent in size to the top screen of the Penn State particle separator was the intake parameter explaining most of the variation in mean ruminal $\mathrm{pH}(\mathrm{r}=0.27)$ and was correlated to time spent ruminating $(r=0.61)$ and chewing $(r=0.61)$.

(Key words: forage particle size, ruminally fermentable carbohydrate, ruminal $\mathrm{pH}$, chewing)

Abbreviation key: $\mathbf{C S}=$ coarse silage, $\mathbf{D C}=$ dry corn, eNDF = effective NDF, eNDFI = effective NDF intake, FS = fine silage, HMC = high moisture corn, $\mathbf{N D F I}=$ NDF intake, peNDF = physically effective fiber, RFC = ruminally fermentable carbohydrate.

\section{INTRODUCTION}

A decrease in ruminal $\mathrm{pH}$ decreases appetite (Britton and Stock, 1987), ruminal motility (Ash, 1959), fiber digestion (Mould et al., 1983), and microbial yield (Hoover, 1986). Decreased ruminal $\mathrm{pH}$ not only affects energy intake and microbial protein yield, but can also cause severe health problems such as laminitis, ruminal ulceration, and liver abscesses (Slyter, 1976).

The relationship between amount of fiber in the diet, particle size, and ruminal $\mathrm{pH}$ has been well documented (Beauchemin, 1991; Grant et al., 1990a; Grant et al., 1990b). However, in a summary of literature data by Pitt et al. (1996), the relationship between mean ruminal $\mathrm{pH}$ and percent forage in the diet using data from dairy cows, steers, and sheep was not very strong $\left(\mathrm{r}^{2}=\right.$ 0.148). This correlation improved somewhat when the authors plotted ruminal $\mathrm{pH}$ versus total NDF in the $\operatorname{diet}\left(\mathrm{r}^{2}=0.296\right)$. Using effective NDF (eNDF), they could explain more of the variation in ruminal $\mathrm{pH}\left(\mathrm{r}^{2}\right.$ $=0.521$ ). Effective NDF is related to the total ability of a feed to replace forage in a ration, so that milk fat percentage is maintained (Mertens, 1997). However, because milk fat percentage of cows in early lactation 
is less responsive to diet, ruminal $\mathrm{pH}$ has been suggested as another response variable for determining fiber requirements in dairy cows (Allen, 1997). Ruminal $\mathrm{pH}$ is not only determined by the fiber content of the diet, but by the balance between the production of fermentation acids and the secretion of buffer (Allen, 1997). There is little information available documenting the influence of ruminally fermentable carbohydrates on $\mathrm{pH}$ at a fixed level of fiber in the diet.

The objectives of this study were to investigate the effects of, and interactions between, level of dietary ruminally fermentable carbohydrates and forage particle size on ruminal $\mathrm{pH}$ and chewing activity at constant level of dietary NDF. Also, the correlations between intake variables and animal responses associated with fiber effectiveness were investigated by including data published in a companion paper.

\section{MATERIALS AND METHODS}

\section{Cows and Diets}

Eight multiparous Holstein cows were assigned randomly to one of two squares in a double $4 \times 4$ Latin square. Cows were fitted with ruminal cannulas and averaged $61 \pm 8 \mathrm{DIM}$ at the start of the experiment. Average BW was $580 \pm 49 \mathrm{~kg}$ at the beginning of the experiment and $617 \pm 53 \mathrm{~kg}$ at the end of the experiment. Experimental periods were $28 \mathrm{~d}$ in duration ( 16 $\mathrm{d}$ of treatment adaptation and $12 \mathrm{~d}$ of data collection). Treatments were arranged in a $2 \times 2$ factorial design. Alfalfa silage that was harvested at $1.9-\mathrm{cm}$ theoretical length of cut provided the coarse silage (CS) for the diets. Finely chopped silage (FS) was obtained by recutting the ensiled alfalfa silage through a $1.9-\mathrm{cm}$ screen in a forage recutter (Gehl, West Bend, WI) daily for the duration of the trial. The two levels of forage particle size were combined with concentrates based on either dry, cracked-shelled corn (DC; 89.9\% DM) or ground, high-moisture shelled corn (HMC; 74.2\% DM). For a more detailed description of diets, see Krause et al. (2002). All diets were formulated to meet or exceed the requirements of a $600-\mathrm{kg}$ multiparous cow producing $45 \mathrm{~kg}$ of milk/d using CPM-Dairy (1997).

Diets were fed as TMR with a ratio of concentrate to forage of 61:39 (DM basis). Cows were fed ad libitum (10\% refusals), and feed was offered twice daily at 0700 and $1900 \mathrm{~h}$ in equal portions. Intakes were recorded daily throughout the experiment. Feed and orts samples were taken twice weekly, and intakes of nutrients were corrected for nutrient contents of orts. Dry matter $\left(60^{\circ} \mathrm{C}\right)$ of feed components was determined weekly, and diets were adjusted to account for changes in DM content.
Cows were cared for according to guidelines of the Research Animal and Resource Committee at the University of Wisconsin-Madison, and all experimental procedures performed on the animals were approved. Cows were housed in stalls bedded with rubber mattresses and wood shavings and were milked twice daily at 0300 and $1500 \mathrm{~h}$ in a milking parlor. Cows were turned outside for 1 to $2 \mathrm{~h}$ daily after being milked, except on days when ruminal $\mathrm{pH}$ and chewing activities were recorded. Total urine output, using indwelling catheters, was also measured in this experiment, along with total tract digestibilities, in sacco disappearance, and rate of passage. The results are all reported in a companion paper (Krause et al, 2002).

\section{Feed Analysis}

Feeds, diets, and orts were analyzed for nutrient content using the methods described in Krause et al. (2002). Particle size of the forages, corn grains, and TMR were determined as described by Krause et al. (2002).

\section{Ruminal pH and VFA Concentrations}

Ruminal $\mathrm{pH}$ was measured continuously for $5 \mathrm{~d}$ using an industrial electrode (Epoxy body sealed combination pH electrode, no. 970061, Sensorex, CA) placed in the ventral sac of the rumen. A weight was attached to the electrode to prevent it from shifting in the rumen. Ruminal $\mathrm{pH}$ were recorded every minute and downloaded to a computer using the program LabTech Notebook 7.5 (LABTECH, Andover, MA). Data acquisition was interrupted twice daily at time of milking. Time during which $\mathrm{pH}$ was below $5.8(\mathrm{~h} / \mathrm{d})$ and area under $5.8(\mathrm{~h} \times \mathrm{pH}$ units/d) were calculated. The area was calculated by adding the absolute value of negative deviations in $\mathrm{pH}$ from $\mathrm{pH} 5.8$ for each minute within a day. The number was divided by 60 in order to get the units $(\mathrm{h} \times \mathrm{pH}$ units/day). Because of the substantial size of the dataset, $\mathrm{pH}$ values were averaged by hour before being analyzed as repeated measurements. Using this new dataset, mean $\mathrm{pH}$, lowest $\mathrm{pH}$ for each cow, and time to nadir were recorded.

Ruminal fluid was sampled 0,4 , and $8 \mathrm{~h}$ after the morning feeding on $2 \mathrm{~d}$. Approximately $100 \mathrm{ml}$ of ruminal fluid was obtained as grab samples of digesta from the anterior dorsal, anterior ventral, medial ventral, posterior dorsal, and posterior ventral locations within the rumen, composited by cow, and strained through two layers of cheesecloth. Samples of $10 \mathrm{ml}$ were acidified with $0.5 \mathrm{ml}$ of $\mathrm{H}_{2} \mathrm{SO}_{4}$ and frozen for later analysis for VFA. These samples were prepared for analysis as follows: 1) sample tubes were thawed and centrifuged 
at $2000 \times g, 4^{\circ} \mathrm{C}$ for $\left.15 \mathrm{~min} ; 2\right)$ supernatant $(1 \mathrm{ml})$ was transferred into a microfuge tube, $0.2 \mathrm{ml}$ of $25 \%$ metaphosphoric acid was added, and the mixture was vortexed before incubating at room temperature for 30 min; and 3) supernatant was transferred into a GLC sample vial for analysis by GLC (Varian 2100, Sunnyvale, CA) with GP $10 \%$ SP- $1200 / 1 \% \mathrm{H}_{3} \mathrm{PO}_{4}$ on $80 / 100$ Chromasorb WAW column packing (Supelco, Bellefonte, PA).

\section{Chewing Activities}

Eating and ruminating behaviors were monitored visually for a 24-h period during the days of ruminal $\mathrm{pH}$ monitoring. Eating and ruminating activities were noted every $5 \mathrm{~min}$, and each activity was assumed to persist for the entire 5-min interval. A meal was defined as at least one observation of eating activity occurring after at least 20 min without eating activity. This criterion was similar to the definition of eating used by Wangsness et al. (1976). They defined a meal as at least 1 min of eating activity after at least 20 min without eating activity. To estimate the time spent eating per kilogram of DMI, the actual intake for that day was used. A period of rumination was defined as at least 5 min of rumination occurring after at least 5 min without ruminating activity. When estimating the number of rumination periods per kilogram of DMI, or time spent ruminating per kilogram of NDF intake (NDFI), the average daily intake measured in that period was used because time spent ruminating was assumed to reflect the DMI of the previous days. Total time spent chewing was calculated as the total time spent eating and ruminating.

\section{Statistical Analysis}

Data on chewing variables were analyzed using the mixed model procedure in SAS (SAS, 1998). Period, level of ruminally fermentable carbohydrate (RFC), particle size of forage, and the interaction of level of RFC and forage were fixed effects in the model, and period was used as a repeated measurement with firstorder auto regressive covariance structure. This covariance structure provided the model with the best fit according to the Schwarz Bayesian Criterion. The random statement included square and cow within square. The model used for chewing data is shown below.

$$
\begin{aligned}
\mathrm{Y}_{\mathrm{ijklm}}= & \mu+\mathrm{S}_{\mathrm{i}}+\mathrm{C}_{\mathrm{j}(\mathrm{i})}+\mathrm{P}_{\mathrm{k}}+\mathrm{M}_{1}+\mathrm{F}_{\mathrm{m}}+(\mathrm{M} \times \mathrm{F})_{\mathrm{lm}} \\
& +\mathrm{e}_{\mathrm{ijklm}},
\end{aligned}
$$

where $\mu$ = overall mean; $\mathrm{S}_{\mathrm{i}}=$ random effect of square (i $=1$ to 2$) ; \mathrm{C}_{\mathrm{j}(\mathrm{i})}=$ random effect of cow within square $(\mathrm{j}=$
1 to 4$) ; P_{k}=$ fixed effect of period analyzed as repeated measurements ( $\mathrm{k}=1$ to 4$) ; \mathrm{M}_{\mathrm{l}}=$ fixed effect of level of RFC ( $1=1$ to 2$) ; F_{m}=$ fixed effect of forage particle size $(\mathrm{m}=1$ to 2$) ;(\mathrm{M} \times \mathrm{F})_{\mathrm{lm}}=$ fixed effect of interaction of $\mathrm{M}_{\mathrm{l}}$ and $\mathrm{F}_{\mathrm{m}}$; and $\mathrm{e}_{\mathrm{ijk} k \mathrm{~m}}=$ random residual error, assumed to be normally distributed.

Ruminal VFA concentrations were analyzed using period, day, and hour as repeated measurements. The model with the best fit according to the Schwarz Bayesian Criterion used a compound symmetry covariance structure for period and day and a first-order auto regressive covariance structure for hour. Ruminal VFA data were analyzed using the following model:

$$
\begin{aligned}
\mathrm{Y}_{\mathrm{ijklmnp}}= & \mu+\mathrm{S}_{\mathrm{i}}+\mathrm{C}_{\mathrm{j}(\mathrm{i})}+\mathrm{P}_{\mathrm{k}}+\mathrm{M}_{\mathrm{l}}+\mathrm{F}_{\mathrm{m}}+(\mathrm{M} \times \mathrm{F})_{l \mathrm{~m}} \\
& +\mathrm{D}_{\mathrm{n}}+\mathrm{H}_{\mathrm{p}}+\mathrm{e}_{\mathrm{ijklmnp}},
\end{aligned}
$$

where $\mu$ = overall mean; $\mathrm{S}_{\mathrm{i}}=$ random effect of square (i $=1$ to 2$) ; \mathrm{C}_{\mathrm{j}(\mathrm{i})}=$ random effect of cow within square $(\mathrm{j}=$ 1 to 4$) ; P_{k}=$ fixed effect of period analyzed as repeated measurements ( $\mathrm{k}=1$ to 4$) ; \mathrm{M}_{1}$ = fixed effect of level of RFC ( $1=1$ to 2$) ; F_{m}=$ fixed effect of forage particle size $(\mathrm{m}=1$ to 2$) ;(\mathrm{M} \times \mathrm{F})_{\mathrm{lm}}=$ fixed effect of interaction of $\mathrm{M}_{\mathrm{l}}$ and $F_{m} ; D_{n}=$ fixed effect of day of sampling analyzed as repeated measurements ( $\mathrm{h}=1$ to 2 ); $\mathrm{H}_{\mathrm{p}}=$ fixed effect of hours post feeding analyzed as repeated measurements ( $p=1$ to 3 ); and $\mathrm{e}_{\mathrm{ijklm}} \mathrm{mp}=$ random residual error, assumed to be normally distributed. No significant interactions were found between day of sampling and main effects, hours postfeeding and main effects, or between day of sampling and hours postfeeding; therefore, these terms were left out of the model.

Before ruminal $\mathrm{pH}$ data were analyzed, $\mathrm{pH}$ values were averaged by hour in order to reduce the number of observations. One day of observations started at the first feeding at $0700 \mathrm{~h}$ and ran until the next morning feeding. Even though cows were not fed restrictively, feeding at 0700 and $1900 \mathrm{~h}$ resulted in a specific biphasic diurnal pattern in $\mathrm{pH}$. Therefore, feeding (first and second) was introduced as a variable in the model, creating a model with repeated measures on four levels: period, day, feeding, and hour post feeding $(12 \mathrm{~h})$. The model with the best fit according to the Schwarz Bayesian Criterion was a model using a compound symmetry covariance structure for period, day, and feeding and a first-order auto regressive covariance structure for hours postfeeding. Only main effects and two-factor interactions were included in the fixed effects portion of the model, as three- and four-factor interactions appeared to be very small. The model was:

$$
\begin{aligned}
\mathrm{Y}_{\mathrm{ijklmnop}}= & \mu+\mathrm{S}_{\mathrm{i}}+\mathrm{C}_{\mathrm{j}(\mathrm{i})}+\mathrm{P}_{\mathrm{k}}+\mathrm{M}_{\mathrm{l}}+\mathrm{F}_{\mathrm{m}}+(\mathrm{M} \times \mathrm{F})_{\mathrm{lm}} \\
& +\mathrm{D}_{\mathrm{n}}+(\mathrm{D} \times \mathrm{M})_{\mathrm{nl}}+(\mathrm{D} \times \mathrm{F})_{\mathrm{nm}}+\mathrm{E}_{\mathrm{o}} \\
& +(\mathrm{E} \times \mathrm{M})_{\mathrm{ol}}+(\mathrm{E} \times \mathrm{F})_{\mathrm{om}}+(\mathrm{D} \times \mathrm{E})_{\mathrm{no}}+\mathrm{H}_{\mathrm{p}} \\
& \text { Journal of Dairy Science Vol. 85, No. 8, } 2002
\end{aligned}
$$




$$
\begin{aligned}
& +(\mathrm{H} \times \mathrm{M})_{\mathrm{pl}}+(\mathrm{H} \times \mathrm{F})_{\mathrm{pm}}+(\mathrm{H} \times \mathrm{D})_{\mathrm{pn}} \\
& +(\mathrm{H} \times \mathrm{E})_{\mathrm{po}}+\mathrm{e}_{\mathrm{ijklmnop}},
\end{aligned}
$$

where $\mu$ = overall mean; $\mathrm{S}_{\mathrm{i}}=$ random effect of square (i $=1$ to 2$) ; \mathrm{C}_{\mathrm{j}(\mathrm{i})}=$ random effect of cow within square $(\mathrm{j}=$ 1 to 4); $\mathrm{P}_{\mathrm{k}}=$ fixed effect of period analyzed as repeated measurements ( $\mathrm{k}=1$ to 4$) ; \mathrm{M}_{1}=$ fixed effect of level of RFC ( $1=1$ to 2$) ; F_{m}=$ fixed effect of forage particle size $(\mathrm{m}=1$ to 2$) ;(\mathrm{M} \times \mathrm{F})_{\mathrm{lm}}=$ fixed effect of interaction of $\mathrm{M}_{\mathrm{l}}$ and $\mathrm{F}_{\mathrm{m}} ; \mathrm{D}_{\mathrm{n}}=$ fixed effect of day of sampling analyzed as repeated measurements $(\mathrm{n}=1$ to 5$) ;(\mathrm{D} \times \mathrm{M})_{\mathrm{nl}}=$ fixed effect of interaction of $D_{n}$ and $M_{1} ;(D \times F)_{n m}=$ fixed effect of interaction of $D_{n}$ and $F_{m} ; E_{0}=$ fixed effect of feeding analyzed as repeated measurement ( $0=1$ to 2$) ;(\mathrm{E} \times$ $M)_{o l}=$ fixed effect of interaction of $E_{0}$ and $M_{1} ;(E \times F)_{o m}$ = fixed effect of interaction of $\mathrm{E}_{\mathrm{o}}$ and $\mathrm{F}_{\mathrm{m}} ;(\mathrm{D} \times \mathrm{E})_{\mathrm{no}}=$ fixed effect of interaction of $\mathrm{D}_{\mathrm{n}}$ and $\mathrm{E}_{\mathrm{o}} ; \mathrm{H}_{\mathrm{p}}=$ fixed effect of hours postfeeding analyzed as repeated measurements $(\mathrm{p}=1$ to 12$) ;(\mathrm{H} \times \mathrm{M})_{\mathrm{pl}}=$ fixed effect of interaction of $\mathrm{H}_{\mathrm{p}}$ and $\mathrm{M}_{1} ;(\mathrm{H} \times \mathrm{F})_{\mathrm{pm}}=$ fixed effect of interaction of $\mathrm{H}_{\mathrm{p}}$ and $\mathrm{F}_{\mathrm{m}} ;(\mathrm{H} \times \mathrm{D})_{\mathrm{pn}}=$ fixed effect of interaction of $\mathrm{H}_{\mathrm{p}}$ and $\mathrm{D}_{\mathrm{n}} ;(\mathrm{H} \times \mathrm{E})_{\mathrm{po}}=$ fixed effect of interaction of $\mathrm{H}_{\mathrm{p}}$ and $\mathrm{E}_{0}$; and $\mathrm{e}_{\mathrm{ijk} \mathrm{kmnop}}=$ random residual error, assumed to be normally distributed.

Significance was declared at $P \leq 0.05$. A trend was considered to exist if $0.05<P \leq 0.10$. All reported values are least square means unless otherwise stated.

\section{RESULTS AND DISCUSSION}

\section{Feed Particle Size, Intakes, and Production}

Particle size of forage, corn grain, and the TMR are described by Krause et al. (2001), along with DM and nutrient intakes. Also, milk production, nutrient digestibilities, and microbial protein yields are reported here.

\section{Ruminal VFA Concentrations}

Ruminal VFA concentrations were similar for the 2 $\mathrm{d}$ of sampling. Total VFA concentration was affected by hour of sampling $(P=0.0046)$, and was $146.0,155.7$, and $152.7 \mathrm{mM}$ for 0,4 , and $8 \mathrm{~h}$ post-a.m. feeding, respectively $(\mathrm{SED}=2.95)$. The same pattern was found for the individual VFA (data not shown). No hour $\times$ diet interaction was found, so only mean values are presented (Table 1). Total ruminal VFA concentration decreased with increasing forage particle size. Diets that increase chewing time and saliva flow may lower the concentration of VFA because saliva flow has a dilution effect and increases the turnover rate of rumen liquid (Sudweeks, 1977). Total ruminal VFA concentration tended to be higher $(P=0.10)$ for HMC than for DC diets, probably reflecting the higher ruminal degradability of HMC compared to DC. Ruminal acetate concen- tration tended to be higher $(P=0.06)$ for DC than for HMC diets, whereas ruminal propionate concentration increased when DC was replaced by HMC. Propionate concentration decreased with increasing forage particle size. When expressed as a percentage of total VFA concentration, the changes mentioned above became highly significant. These changes in acetate and propionate concentrations resulted in an increase in acetate:propionate ratio when forage particle size was increased, and a decrease when DC was replaced by HMC. Acetate:propionate ratios below 2 are often associated with milk fat depression (Erdman, 1988). However, in this study very low ratios were observed without a concurrent depression in milk fat [for milk fat percentage and production results see Krause et al. (2001)]. Butyrate concentration was unaffected by forage particle size but was higher for DC than for HMC diets. When expressed as a percentage of total VFA, butyrate concentration was higher for DC than for HMC and increased with increasing forage particle size.

\section{Chewing Activities}

Chewing activities are reported in Table 2. Cows spent between 3.9 and $5 \mathrm{~h}$ eating per day, which is within the normal range for cows consuming 4 to $6 \mathrm{~kg}$ of NDF per day (Beauchemin, 1991). Time spent eating was affected by level of RFC and by forage particle size; eating time was higher for DC than for HMC diets, possibly due to the higher DM content of DC compared with HMC, as moisture content has been shown to affect eating rate (Bailey, 1961). Time spent eating also increased with increasing forage particle size. However, when time spent eating was expressed per $\mathrm{kg}$ of DMI, increasing forage particle size decreased time spent eating for HMC diets but increased eating time for DC diets.

Number of meals decreased when forage particle size increased, whereas the duration of each meal increased. The number of meals per $\mathrm{kg}$ of $\mathrm{DMI} / \mathrm{d}$ decreased with increasing forage particle size. The eating pattern was similar for cows fed either silage with eating activity being highest the hour after each of the two feedings (Figure 1). The increased time spent eating with increasing forage particle size (237 min vs. $274 \mathrm{~min}$ ) was evenly distributed throughout the day.

Time spent ruminating ranged from 4.8 to $8.4 \mathrm{~h} / \mathrm{d}$, which is consistent with the normal range of 4 to $7 \mathrm{~h}$ for dairy cows eating 4 to $6 \mathrm{~kg}$ of NDF/d (Beauchemin, 1991). Time spent ruminating per day increased when forage particle size was increased. This increase was caused by an increase in number of rumination periods per day and a trend towards an increase $(P=0.07)$ in the duration of each rumination period. Time spent 
Table 1. Effects of level of ruminally fermentable carbohydrates and forage particle size on ruminal VFA concentrations.

\begin{tabular}{|c|c|c|c|c|c|c|c|c|}
\hline \multirow[b]{2}{*}{$\begin{array}{l}\text { Dependent } \\
\text { variable }\end{array}$} & \multicolumn{4}{|c|}{ Treatments $^{1}$} & \multirow[b]{2}{*}{$\mathrm{SED}^{2}$} & \multicolumn{3}{|c|}{$\begin{array}{l}\text { Statistical significance } \\
\quad(P \text {-value })\end{array}$} \\
\hline & HMCFS & HMCCS & DCFS & DCCS & & $\mathrm{RFC}^{3}$ & Forage & $\begin{array}{l}\mathrm{RFC} \\
\times \text { Forage }\end{array}$ \\
\hline \multicolumn{9}{|l|}{ VFA, $\mathrm{m} M$} \\
\hline Total & 161.5 & 148.4 & 151.1 & 144.9 & 5.6 & 0.10 & 0.03 & 0.40 \\
\hline Acetate (A) & 78.9 & 77.4 & 82.8 & 82.5 & 3.2 & 0.06 & 0.67 & 0.78 \\
\hline Propionate $(\mathrm{P})$ & 52.4 & 43.7 & 39.8 & 35.2 & 2.8 & 0.001 & 0.003 & 0.32 \\
\hline Butyrate & 19.6 & 19.6 & 20.8 & 22.5 & 1.4 & 0.05 & 0.38 & 0.39 \\
\hline $\mathrm{A}: \mathrm{P}$ ratio & 1.60 & 1.90 & 2.23 & 2.45 & 0.12 & 0.0001 & 0.03 & 0.68 \\
\hline \multicolumn{9}{|l|}{ Molar \% } \\
\hline Acetate & 49.4 & 52.5 & 54.9 & 57.2 & 1.1 & 0.0001 & 0.003 & 0.64 \\
\hline Propionate & 32.6 & 29.1 & 26.2 & 24.2 & 1.3 & 0.0001 & 0.007 & 0.43 \\
\hline Butyrate & 12.2 & 13.2 & 13.2 & 15.7 & 1.0 & 0.009 & 0.04 & 0.52 \\
\hline
\end{tabular}

\footnotetext{
${ }^{1}$ Treatments: HMCFS = High-moisture corn and fine silage, HMCCS = high-moisture corn and coarse silage, DCFS = dry corn and fine silage, DCCS = Dry corn and coarse silage.

${ }^{2} \mathrm{SED}=$ Standard error of difference

${ }^{3} \mathrm{RFC}=$ Ruminally fermentable carbohydrate.
}

ruminating also tended to increase when DC was replaced by HMC $(P=0.08)$. When expressed per $\mathrm{kg}$ of NDF intake per day, increasing forage particle size increased time spent ruminating and so did replacing DC with HMC. Number of rumination periods also tended $(P=0.07)$ to increase when DC was replaced with HMC. Assuming alfalfa silage was the only component of the diet that would stimulate rumination, the increase in time spent ruminating/kg of NDF intake when HMC replaced DC may indicate an adaptive response by the animals to the increase in RFC. The effect of the animal response would be to increase the low ruminal $\mathrm{pH}$ or to enhance particulate and fluid movement from the rumen. A similar increase in time spent ruminating per kilogram of alfalfa silage intake, was observed by Woodford and Murphy (1988) when the ratio of alfalfa pellets to alfalfa silage was increased in diets fed to early lactation cows.

Daily rumination pattern for cows fed FS and CS is shown in Figure 2. Rumination activity was highest during the periods between the two feedings, and the higher daily rumination activity for cows fed CS vs. FS (485 vs. $320 \mathrm{~min}$ ) was evenly distributed throughout the day. Total time spent chewing per day and chewing time per $\mathrm{kg}$ of DMI/d increased with increasing forage particle size $(P=0.0001)$ but was unaffected by level of RFC.

Table 2. Effects of level of ruminally fermentable carbohydrates and forage particle size on chewing behavior.

\begin{tabular}{|c|c|c|c|c|c|c|c|c|}
\hline \multirow[b]{2}{*}{ Dependent variable } & \multicolumn{5}{|c|}{ Treatments $^{1}$} & \multicolumn{3}{|c|}{ Statistical significance ( $P$-value) } \\
\hline & HMCFS & HMCCS & DCFS & DCCS & $\mathrm{SED}^{2}$ & $\mathrm{RFC}^{3}$ & Forage & $\begin{array}{l}\mathrm{RFC} \\
\times \text { Forage }\end{array}$ \\
\hline Time, $\mathrm{min} / \mathrm{d}$ & 232 & 248 & 241 & 300 & 19 & 0.04 & 0.01 & 0.13 \\
\hline Time/DMI per $\mathrm{d}, \mathrm{min} / \mathrm{kg}$ & 10.1 & 9.8 & 9.8 & 12.2 & 0.8 & 0.07 & 0.09 & 0.02 \\
\hline Meals, number/d & 13.2 & 12.2 & 13.2 & 11.9 & 0.7 & 0.76 & 0.03 & 0.76 \\
\hline Duration of meal, min & 21.1 & 27.4 & 22.0 & 25.7 & 2.4 & 0.62 & 0.04 & 0.12 \\
\hline Time, $\min / \mathrm{d}$ & 351 & 502 & 288 & 468 & 38 & 0.08 & 0.0001 & 0.60 \\
\hline Time/NDF intake per day, $\mathrm{min} / \mathrm{kg}$ & 63 & 96 & 54 & 83 & 6 & 0.03 & 0.0001 & 0.60 \\
\hline Rumination periods, number/d & 12.5 & 16.4 & 10.9 & 14.2 & 1.4 & 0.07 & 0.0016 & 0.76 \\
\hline Duration of rumination period, min & 28.7 & 31.1 & 23.3 & 26.6 & 2.4 & 0.13 & 0.07 & 0.12 \\
\hline \multicolumn{9}{|l|}{ Chewing } \\
\hline Time, $\mathrm{min} / \mathrm{d}$ & 587 & 742 & 519 & 781 & 47 & 0.66 & 0.0001 & 0.13 \\
\hline Time/DMI per $\mathrm{d}, \mathrm{min} / \mathrm{kg}$ & 24.9 & 30.6 & 21.7 & 30.9 & 1.7 & 0.24 & 0.0001 & 0.16 \\
\hline
\end{tabular}

\footnotetext{
${ }^{1}$ Treatments: HMCFS = High-moisture corn and fine silage, HMCCS = high-moisture corn and coarse silage, DCFS = dry corn and fine silage, DCCS $=$ Dry corn and coarse silage.

${ }^{2} \mathrm{SED}=$ Standard error of difference.

${ }^{3} \mathrm{RFC}=$ Ruminally fermentable carbohydrate.
} 


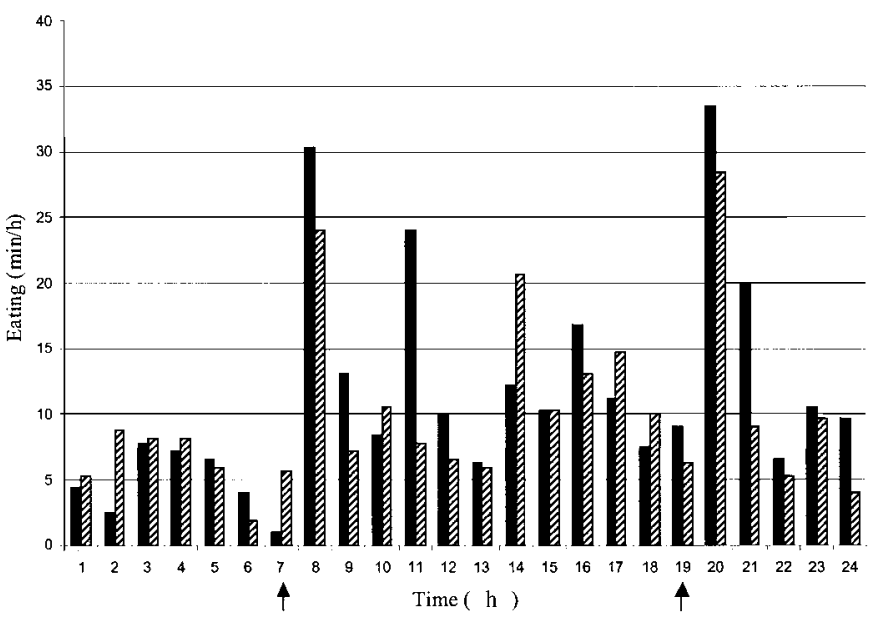

Figure 1. Daily eating activity for CS and FS diets. Arrows indicate time of feeding. CS: solid; FS: striped. CS = Coarse silage, FS = fine silage.

Cassida and Stokes (1986) estimated saliva flow rates of $150 \mathrm{ml} / \mathrm{min}, 177 \mathrm{ml} / \mathrm{min}$, and $300 \mathrm{ml} / \mathrm{min}$ during resting, eating, and ruminating, respectively. Using these estimated flow rates, the HMCCS diet would have resulted in the highest saliva production of $296.9 \mathrm{~L} / \mathrm{d}$, followed by $296.0 \mathrm{~L} / \mathrm{d}, 275.5 \mathrm{~L} / \mathrm{d}$, and $264.5 \mathrm{~L} / \mathrm{d}$ for DCCS, HMCFS, and DCFS, respectively. Since saliva composition has not been shown to be greatly affected by diet (Bailey and Balch, 1961a, 1961b), the HMCCS diet likely provided the greatest salivary buffering, whereas the DCFS provided the least. These two diets were not the diets with the highest and lowest ruminal

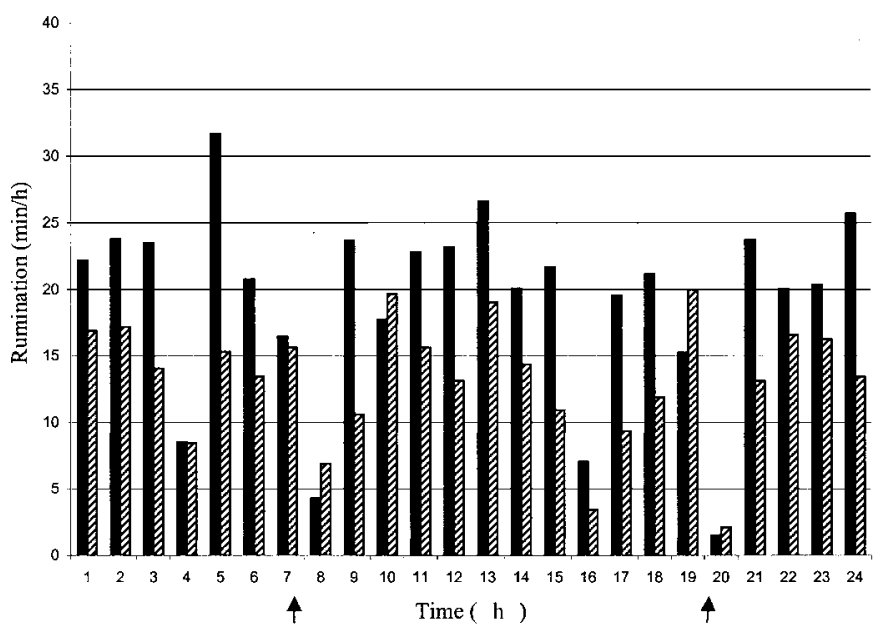

Figure 2. Daily rumination activity for CS and FS diets. Arrows indicate time of feeding. CS: solid; FS: striped. CS = Coarse silage, $\mathrm{FS}=$ fine silage.
$\mathrm{pH}$, respectively (Table 3 ) indicating that salivary buffering is only one of many factors determining ruminal $\mathrm{pH}$. Our study indicates that increasing the fermentability of the dietary carbohydrates lowers rumen $\mathrm{pH}$, an effect that could not be predicted based on time spent chewing or salivary buffering.

Sudweeks et al. (1981) reported that the minimum time spent chewing per $\mathrm{kg}$ of DMI for the production of 3.5\% milk fat was 31 min for cows producing 19 to $20 \mathrm{~kg}$ milk/d. However, the minimum time spent chewing per $\mathrm{kg}$ of DMI required for a certain milk fat percentage depends on total DMI (Sudweeks et al., 1981). Woodford et al. (1986) used cows producing 28.9 to 31.2 $\mathrm{kg}$ of milk/d and reported that 22.3, 21.7, and $23.2 \mathrm{~min}$ of chewing $/ \mathrm{kg}$ of DMI were needed to maintain milkfat percentages of $3.2,3.3$, and 3.6 , respectively. In a study by Woodford and Murphy (1988), total chewing times of $28.2,24.1$, and $20.0 \mathrm{~min} / \mathrm{kg}$ DMI resulted in milk fat percentages of 3.0, 2.9, and 2.6, respectively, using cows producing between 31.8 and $35.5 \mathrm{~kg}$ milk/ d. In the current study, total chewing times of 24.9, $30.6,21.7$, and $30.9 \mathrm{~min} / \mathrm{kg}$ of DMI resulted in milk fat percentages of $3.42,3.60,3.48$, and 3.62 , respectively (Krause et al., 2002). The discrepancies between studies in minimum chewing time required to sustain $3.5 \%$ milk fat indicate that this concept is flawed. Milk fat content is the result of numerous animal and dietary factors and not simply chewing time.

Chewing activity is the animal response associated with physical effectiveness of the NDF fraction (Mertens, 1997). Physically effective NDF (peNDF) is a reflection of the physical characteristics of the fiber. Because peNDF relates only to the physical properties of fiber, peNDF is a more restricted concept than eNDF. In this study, cows fed CS chewed more than cows fed FS. When time spent chewing was corrected for NDF intake, FS was $73 \%$ as effective at promoting chewing as CS. Thus, reducing forage particle size in this study decreased the physical effectiveness factor of forage NDF. Although physical effectiveness of FS was less than CS, cows fed FS diets still spent more than $9 \mathrm{~h} / \mathrm{d}$ chewing. The fact that minutes spent ruminating per kilogram of NDF intake increased when HMC replaced DC indicates that physical effectiveness of forages is affected by other dietary components such as corn grain moisture and fermentability. This is important to consider when assessing physical effectiveness factors for forages based on chewing activity.

\section{Ruminal pH}

Both level of RFC and forage particle size affected mean ruminal $\mathrm{pH}$, but forage particle size to a greater degree than level of RFC (Table 3). Decreasing forage 
Table 3. Effects of level of ruminally fermentable carbohydrates and forage particle size on ruminal $\mathrm{pH}$.

\begin{tabular}{|c|c|c|c|c|c|c|c|c|}
\hline \multirow[b]{2}{*}{$\begin{array}{l}\text { Dependent } \\
\text { variable }\end{array}$} & \multicolumn{4}{|c|}{ Treatments $^{1}$} & \multirow[b]{2}{*}{$\mathrm{SED}^{2}$} & \multicolumn{3}{|c|}{ Statistical significance ( $P$-value $)$} \\
\hline & HMCFS & HMCCS & DCFS & DCCS & & $\mathrm{RFC}$ & Forage & $\begin{array}{l}\mathrm{RFC} \\
\times \text { Forage }\end{array}$ \\
\hline Minimum daily $\mathrm{pH}$ & 5.37 & 5.56 & 5.59 & 5.73 & 0.07 & 0.0003 & 0.002 & 0.64 \\
\hline Time post feeding for minimum $\mathrm{pH}, \mathrm{h}$ & 4.9 & 4.8 & 5.7 & 4.7 & 0.7 & 0.38 & 0.27 & 0.37 \\
\hline Time below $\mathrm{pH} 5.8, \mathrm{~h} / \mathrm{d}$ & 14.3 & 7.2 & 9.3 & 5.5 & 1.4 & 0.003 & 0.0001 & 0.11 \\
\hline Area below $\mathrm{pH} 5.8, \mathrm{~h} \times \mathrm{pH}$ units/day & 5.0 & 2.1 & 2.9 & 1.5 & 0.9 & 0.01 & 0.0002 & 0.15 \\
\hline
\end{tabular}

\footnotetext{
${ }^{1}$ Treatments: HMCFS = High-moisture corn and fine silage, HMCCS = high-moisture corn and coarse silage, DCFS = dry corn and fine silage, DCCS $=$ Dry corn and coarse silage.

${ }^{2} \mathrm{SED}=$ Standard error of difference.

${ }^{3} \mathrm{RFC}=$ Ruminally fermentable carbohydrate.
}

particle size decreased $\mathrm{pH}$ from 6.02 to 5.81, whereas replacing DC with HMC decreased $\mathrm{pH}$ from 5.99 to 5.85. No interaction between forage particle size and level of RFC on ruminal $\mathrm{pH}$ was observed. In the empirical prediction of ruminal $\mathrm{pH}$ based on literature data, Allen (1997) found that forage particle length had the most influence on the range in ruminal $\mathrm{pH}$ compared with NDF content of diets, intake of OM, or ruminally digested OM. All four diets resulted in similar diurnal patterns (Figure 3). However, diets containing FS resulted in 'flatter' diurnal $\mathrm{pH}$ curves than did CS diets. Effects of feedings on $\mathrm{pH}$ were not as pronounced in FS diets as in CS diets.

Minimum daily $\mathrm{pH}$ decreased from 5.66 to 5.47 when level of RFC was increased, and decreased from 5.65 to 5.48 when forage particle size was decreased. Minimum $\mathrm{pH}$ after the morning feeding was $0.08 \mathrm{u}$ higher than minimum $\mathrm{pH}$ occurring after the evening feeding. Nadir occurred between 4.7 and $5.7 \mathrm{~h}$ postfeeding, and time of nadir in relation to feeding was not affected by level of RFC or forage particle size. When comparing these

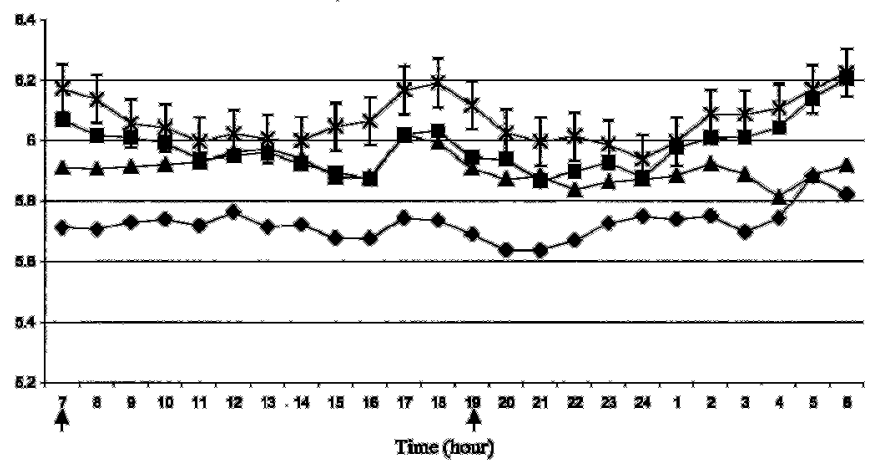

Figure 3. Diurnal fluctuations in ruminal $\mathrm{pH}$ for diets differing in forage particle size and level of ruminally fermentable carbohydrate. Arrows indicate time of feeding. HMCFS: $\bullet$ HMCCS: $\mathbf{\square}$; DCFS: $\mathbf{\Delta}$; DCCS: $\times$. HMCFS $=$ High-moisture corn and fine silage, HMCCS = high-moisture corn and coarse silage, DCFS = dry corn and fine silage, DCCS $=$ dry corn and coarse silage. nadir $\mathrm{pH}$ values to results from other studies, it is important to consider that the values reported here were based on $60 \mathrm{pH}$ measurements averaged by hour and not on the absolute minimum $\mathrm{pH}$ values measured. The nadir values reported in the current study will, therefore, likely be higher than values reported elsewhere. Time spent below pH 5.8/d increased from 7.4 to $10.8 \mathrm{~h}$ when HMC replaced $\mathrm{DC}$, but forage particle size affected time spent below 5.8 to a greater extent with an increase from 6.4 to $11.8 \mathrm{~h} / \mathrm{d}$ when forage particle size was decreased. Area below pH 5.8 increased when HMC replaced DC and when forage particle size decreased. The effects of level of RFC and forage particle size on area below 5.8 was more pronounced than the effect on mean $\mathrm{pH}$ when expressed as a percentage change. This emphasizes the importance of considering not only mean ruminal $\mathrm{pH}$, but also diurnal variations when assessing the effect of diets on rumen health. Woodford and Murphy (1988) also found no effect of forage particle size on mean $\mathrm{pH}$ measured every second hour for $24 \mathrm{~h}$ but did find a significant increase in area below $\mathrm{pH} 6$, when forage particle size was decreased. Based on mean $\mathrm{pH}$ and minimum $\mathrm{pH}$ values, none of the diets fed in this study resulted in cows suffering from acute ruminal acidosis or subacute ruminal acidosis, which are defined by $\mathrm{pH}<5$ and $\mathrm{pH}<5.6$, respectively (Owens et al., 1996).

Ruminal $\mathrm{pH}$ was not different $(P=0.87)$ from day to day and was not affected $(P=0.39)$ by feeding (morning vs. evening; data not shown). No interactions between day and main effects or feeding and on $\mathrm{pH}$ were observed. Ruminal $\mathrm{pH}$ declined immediately after feeding and subsequently started to increase again. However, this postfeeding pattern in ruminal $\mathrm{pH}$ differed depending on forage particle size (Figure 4), as shown by a significant forage by hours postfeeding interaction $(P$ $=0.0002$; data not shown). When cows were fed CS, $\mathrm{pH}$ started out higher at the time of feeding $(\mathrm{pH}=6.07)$ than when cows were fed FS $(\mathrm{pH}=5.80)$ and decreased $0.13 \mathrm{u}$ to nadir $5 \mathrm{~h}$ postfeeding and then increased to 


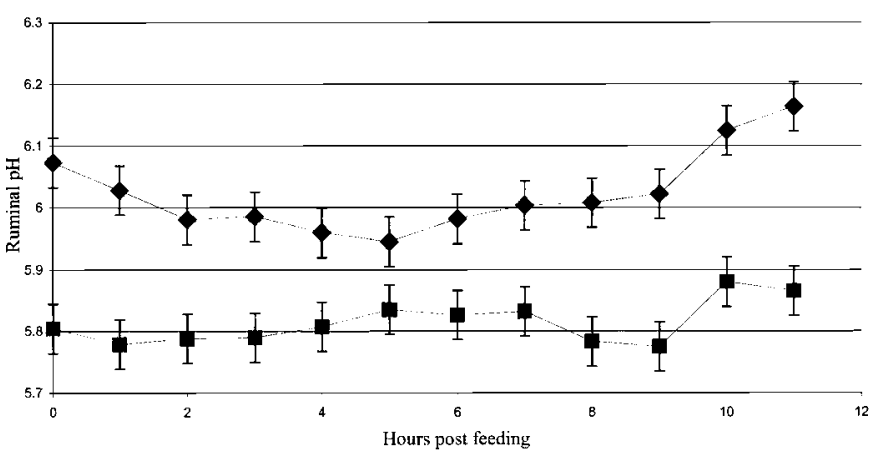

Figure 4. Effect of forage particle size on rumen $\mathrm{pH}$ pattern postfeeding. CS: $\$$; FS: $\mathbf{\square}$. CS = Coarse silage, FS = fine silage.

$\mathrm{pH} 6.16$ at the time of the next feeding. When cows were fed FS, the decline in $\mathrm{pH}$ post feeding was much less pronounced, with nadir occurring $9 \mathrm{~h}$ postfeeding and the decline to nadir only being $0.02 \mathrm{pH}$ units.

The pattern in ruminal $\mathrm{pH}$ differed between the two daily feedings as shown by an interaction between feeding and hours after feeding $(P=0.0025$; data not shown). The pattern associated with the evening feeding was characterized by a lower initial $\mathrm{pH}$ than that for the morning feeding (5.91 vs. 5.96), but a higher $\mathrm{pH}$ at the time of the next feeding than for the morning feeding (Figure 5). Also, nadir after feeding was reached $2 \mathrm{~h}$ postfeeding in the evening, but $9 \mathrm{~h}$ postfeeding in the morning. This difference in ruminal $\mathrm{pH}$ pattern between the two feedings was probably caused by the diurnal eating and rumination pattern. Time spent eating was higher during the hours between the morning and the evening feeding (148 $\mathrm{min}$ ) than between the evening and the morning feeding $(107 \mathrm{~min})$. The greater time spent eating probably translated into a higher DMI during the day compared with during the night, resulting in a lower $\mathrm{pH}$ at the time of the evening feeding than at the time of the morning feeding. Time

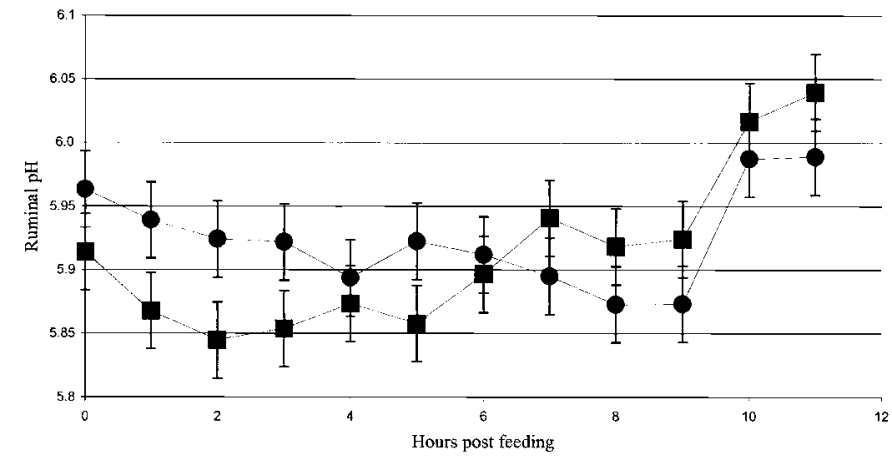

Figure 5. Effect of feeding (morning vs. evening) on ruminal $\mathrm{pH}$ pattern. Morning feeding: $\mathbf{0}$; Evening feeding: $\mathbf{\square}$. spent ruminating was similar for the two periods between feedings (189 vs. $200 \mathrm{~min}$ ).

In a literature review of data from feeding trials, Erdman (1988) found no relationship between ruminal $\mathrm{pH}$ and milk fat percentage. This is in contrast to a more recent review by Allen (1997), who reported a positive relationship between ruminal $\mathrm{pH}$ and milk fat percentage. Milk fat percentage is often used as an animal response variable for evaluating fiber effectiveness and fiber requirements of dairy cows, but ruminal $\mathrm{pH}$, ruminal VFA pattern, and time spent chewing have also been suggested. The animal response variable most closely related to animal health has not been determined. But as stated by Mertens (1997), milk fat percentage might not be the most sensitive variable, as it is a common field observation that lameness can be observed in herds showing no milk fat depression. Also, the current study demonstrates a significant effect of forage particle size and level of RFC on VFA concentrations, ruminal $\mathrm{pH}$ and chewing activity, but not on milk fat percentage [see Krause et al., (2002) for data on milk production]. No adverse effects of diets on cow health were observed in this study, but the short-term nature of the study did not allow for any conclusions with regard to dietary effects on cow health.

\section{Correlations Between Ruminal pH, Milk Fat Percentage, Chewing Activity, and Intake Parameters}

The relationship between intake variables and animal responses associated with fiber effectiveness were investigated using Pearson correlation coefficients (Table 4). Data on intakes and milk fat percentage were from Krause et al. (2001). Intake of NDF was not correlated with chewing activity, milk fat percentage, or ruminal $\mathrm{pH}$ even though the range in NDF intake was from 4.36 to $6.70 \mathrm{~kg} / \mathrm{d}$ in this study (Krause et al., 2002). Intake of eNDF (eNDFI) tended to correlate positively with time spent ruminating $(P=0.10)$ and time spent chewing $(P=0.06)$ but showed no relationship with milk fat percentage or ruminal $\mathrm{pH}$.

Intake of feed from the top and middle screen and pan of the Penn State particle size separator was approximated from the distribution of TMR and orts on the UW forage particle size separator (ASAE standard S424, American National Standards Institute, 1988) and DMI. Dry matter content was assumed to be equal for the different screens. The intake of DM from the top screen was positively correlated with time spent ruminating and chewing. This was also the intake variable explaining most of the variation in mean ruminal $\mathrm{pH}(\mathrm{r}=0.27)$; however, this correlation was not significant $(P=0.15)$. Furthermore, intake of DM from the 
Table 4. Pearson correlation coefficients for variables related to fiber intake and fiber effectiveness. $P$-values are presented in parentheses.

\begin{tabular}{|c|c|c|c|c|c|c|c|c|c|c|c|}
\hline & $\begin{array}{l}\text { NDFI, }{ }^{1} \\
\mathrm{~kg} / \mathrm{d}\end{array}$ & $\begin{array}{l}\text { ENDFI, } \\
\mathrm{kg} / \mathrm{d}\end{array}$ & $\begin{array}{l}\text { Top } \\
\text { screen } \\
\text { DMI, }{ }^{3} \\
\text { kg/d } \\
\end{array}$ & $\begin{array}{l}\text { Middle } \\
\text { screen } \\
\text { DMI } \\
\mathrm{kg} / \mathrm{d}\end{array}$ & $\begin{array}{l}\text { Pan } \\
\mathrm{DMI}, \\
\mathrm{kg} / \mathrm{d}\end{array}$ & $\begin{array}{l}\text { Rumination, } \\
\mathrm{min} / \mathrm{d}\end{array}$ & $\begin{array}{l}\text { Chewing, } \\
\mathrm{min} / \mathrm{d}\end{array}$ & $\begin{array}{l}\text { Milk } \\
\text { fat, } \\
\%\end{array}$ & $\begin{array}{l}\text { Mean } \\
\text { ruminal } \\
\mathrm{pH}^{4}\end{array}$ & $\begin{array}{l}\text { Time }<\mathrm{pH} \\
5.8, \mathrm{~h}\end{array}$ & $\begin{array}{l}\text { Area }<\mathrm{pH} \\
5.8, \mathrm{~h} \times \mathrm{pH} \\
\text { units/d }\end{array}$ \\
\hline $\begin{array}{l}\text { NDFI, kg/d } \\
\text { eNDFI, kg/d }\end{array}$ & $\begin{array}{c}1 \\
0.97 \\
(<0.0001)\end{array}$ & 1 & & & & & & & & & \\
\hline Top screen DMI, kg/d & $\begin{array}{c}0.04 \\
(0.84)\end{array}$ & $\begin{array}{c}0.27 \\
(0.16)\end{array}$ & 1 & & & & & & & & \\
\hline Middle screen DMI, kg/d & $\begin{array}{l}0.65 \\
(0.0001)\end{array}$ & $\begin{array}{l}0.55 \\
(0.002)\end{array}$ & $\begin{array}{l}-0.30 \\
(0.12)\end{array}$ & 1 & & & & & & & \\
\hline Pan DMI, kg/d & $\begin{array}{c}0.31 \\
(0.10)\end{array}$ & $\begin{array}{c}0.12 \\
(0.55)\end{array}$ & $\begin{array}{l}-0.89 \\
(<0.0001)\end{array}$ & $\begin{array}{l}0.60 \\
(0.0006)\end{array}$ & 1 & & & & & & \\
\hline Rumination, $\mathrm{min} / \mathrm{d}$ & $\begin{array}{c}0.16 \\
(0.39)\end{array}$ & $\begin{array}{c}0.30 \\
(0.10)\end{array}$ & $\begin{array}{l}0.61 \\
(0.0003)\end{array}$ & $\begin{array}{c}-0.19 \\
(0.32)\end{array}$ & $\begin{array}{l}-0.28 \\
(0.0014)\end{array}$ & 1 & & & & & \\
\hline Chewing, $\min / \mathrm{d}$ & $\begin{array}{c}0.19 \\
(0.29)\end{array}$ & $\begin{array}{c}0.34 \\
(0.06)\end{array}$ & $\begin{array}{l}0.61 \\
(0.0003)\end{array}$ & $\begin{array}{c}-0.15 \\
(0.44)\end{array}$ & $\begin{array}{c}-0.26 \\
(0.16)\end{array}$ & $\begin{array}{c}0.94 \\
(<0.0001)\end{array}$ & 1 & & & & \\
\hline Milk fat, $\%$ & $\begin{array}{c}-0.02 \\
(0.90)\end{array}$ & $\begin{array}{c}0.02 \\
(0.91)\end{array}$ & $\begin{array}{c}0.11 \\
(0.56)\end{array}$ & $\begin{array}{c}-0.07 \\
(0.73)\end{array}$ & $\begin{array}{c}-0.07 \\
(0.74)\end{array}$ & $\begin{array}{c}-0.12 \\
(0.53)\end{array}$ & $\begin{array}{c}-0.03 \\
(0.86)\end{array}$ & 1 & & & \\
\hline Mean ruminal $\mathrm{pH}$ & $\begin{array}{c}0.05 \\
(0.78)\end{array}$ & $\begin{array}{c}0.13 \\
(0.48)\end{array}$ & $\begin{array}{c}0.27 \\
(0.15)\end{array}$ & $\begin{array}{l}-0.06 \\
(0.75)\end{array}$ & $\begin{array}{c}-0.18 \\
(0.34)\end{array}$ & $\begin{array}{c}0.03 \\
(0.86)\end{array}$ & $\begin{array}{c}0.14 \\
(0.46)\end{array}$ & $\begin{array}{c}0.41 \\
(0.02)\end{array}$ & 1 & & \\
\hline Time $<$ ph $5.8, \mathrm{~h}$ & $\begin{array}{c}-0.006 \\
(0.98)\end{array}$ & $\begin{array}{l}-0.10 \\
(0.59)\end{array}$ & $\begin{array}{c}-0.32 \\
(0.09)\end{array}$ & $\begin{array}{c}0.12 \\
(0.53)\end{array}$ & $\begin{array}{c}0.21 \\
(0.26)\end{array}$ & $\begin{array}{c}-0.03 \\
(0.86)\end{array}$ & $\begin{array}{c}-0.15 \\
(0.42)\end{array}$ & $\begin{array}{l}-0.55 \\
(0.001)\end{array}$ & $\begin{array}{l}-0.96 \\
(<0.0001)\end{array}$ & 1 & \\
\hline Area $<\mathrm{pH} 5.8, \mathrm{~h} \times \mathrm{pH}$ units/d & $\begin{array}{r}-0.007 \\
(0.97)\end{array}$ & $\begin{array}{c}-0.09 \\
(0.62)\end{array}$ & $\begin{array}{c}-0.30 \\
(0.10)\end{array}$ & $\begin{array}{c}0.06 \\
(0.76)\end{array}$ & $\begin{array}{c}0.11 \\
(0.57)\end{array}$ & $\begin{array}{l}-0.04 \\
(0.84)\end{array}$ & $\begin{array}{c}-0.16 \\
(0.38)\end{array}$ & $\begin{array}{l}-0.57 \\
(0.0007)\end{array}$ & $\begin{array}{l}-0.91 \\
(<0.0001)\end{array}$ & $\begin{array}{c}0.94 \\
(<0.0001)\end{array}$ & 1 \\
\hline
\end{tabular}

${ }^{1} \mathrm{NDFI}=\mathrm{NDF}$ intake.

${ }^{2} \mathrm{eNDFI}=\mathrm{eNDF}$ intake.

${ }^{3}$ Intakes of DM from top screen, middle screen, and pan of Penn State particle size separator (adapted from distribution on UW forage particle size separator). Corrected for particle size distribution of orts but assuming equal DM of fractions retained on screens and pan.

${ }^{4}$ Ruminal $\mathrm{pH}$ averaged across the 5 days of data collection in each experimental period. 
top screen tended to correlate negatively with both time spent below pH $5.8(P=0.09)$ and area below pH 5.8 $(P=0.10)$. Intake of DM from the pan was negatively correlated to time spent ruminating. None of the intake variables was correlated to milk fat percentage. The two animal response variables, ruminal $\mathrm{pH}$ and milk fat percentage, were positively correlated, but neither of them were correlated to time spent ruminating or chewing. Time spent below pH 5.8 and area below $\mathrm{pH}$ 5.8 were negatively correlated to milk fat percentage but, like mean ruminal $\mathrm{pH}$, neither of them were correlated to time spent ruminating or chewing.

The dataset used here is relatively small, so conclusions based on these results should be made with caution. However, the correlations reported here indicate that the simple measurement of feed retained on the top screen of the Penn State particle size separator is a more useful parameter than NDF or eNDF when assessing effective fiber adequacy of a dairy cow ration. But, as this study demonstrates, not only forage particle size, but also corn fermentability affects ruminal $\mathrm{pH}$, which is not accounted for when using the Penn State particle size separator.

\section{CONCLUSIONS}

Increasing the level of RFC and decreasing forage particle size increased the concentration of propionate in the rumen and decreased the acetate:propionate ratio to $<2$. Decreasing forage particle size increased total concentration of VFA in the rumen. Both level of RFC and forage particle size affected ruminal $\mathrm{pH}$, but forage particle size to a greater degree than level of RFC. No interaction between forage particle size and level of $\mathrm{RFC}$ on ruminal $\mathrm{pH}$ was observed. Minimum daily $\mathrm{pH}$ decreased with increasing RFC and decreasing forage particle size. Both time spent below $\mathrm{pH} 5.8$ per day and area below pH 5.8 increased when level of RFC was increased and also increased with decreasing forage particle size. The effects of level of RFC and forage particle size on area below 5.8 seemed to be more pronounced than the effect on mean $\mathrm{pH}$, emphasizing the importance of considering not only mean $\mathrm{pH}$, but also diurnal variations, when assessing the effect of diets on rumen health.

Increasing level of RFC reduced time spent eating, as did reducing forage particle size. Cows spent less time ruminating per day and per kilogram of NDF intake when forage particle size was decreased. Also, feeding high moisture corn instead of dry corn increased time spent ruminating per kilogram of NDF intake, possibly caused by an adaptive response by the animals to the increase in level of RFC. This observation indicates that physical effectiveness of forages is affected by other dietary components. Total time spent chewing per day and per kilogram of NDF intake per day increased with increasing forage particle size but was unaffected by level of RFC.

Intake of NDF was not correlated to ruminal $\mathrm{pH}$, chewing activity, or milk fat percentage, whereas intake of eNDF tended to correlate positively with time spent ruminating and chewing. Intake of particulate DM equivalent to that retained on the top screen of the Penn State particle separator box was positively correlated with time spent ruminating and chewing, and tended to correlate negatively with both time spent below pH 5.8 and area below 5.8. This was the intake variable explaining most of the variation in mean ruminal $\mathrm{pH}$. None of the intake variables or chewing activity was correlated with milk fat percentage. Mean ruminal $\mathrm{pH}$ was positively correlated, and time spent below $\mathrm{pH}$ 5.8 and area below 5.8 were negatively correlated to milk fat percentage.

As demonstrated in this study, the effectiveness of $\mathrm{NDF}$ in a diet depends on the animal response used to measure it. The response variable ruminal $\mathrm{pH}$ was shown to depend not only on forage particle size, but also on the amount of ruminally fermentable carbohydrates. However, no interaction between forage particle size and carbohydrate fermentability was found on rumen $\mathrm{pH}$ in this study. The fact that these effects seem to be additive should facilitate the inclusion of both factors in dairy ration formulation and evaluation programs.

This study indicates that intake of particulate DM equivalent to that retained on the top screen of the Penn State particle separator box might be the most useful tool when evaluating fiber adequacy in dairy cows rations like the ones fed in this study. However, more research is needed to quantify the effects of ruminally fermentable carbohydrates on cow health and production, so that both fermentation acid production and physically effective fiber can be considered when formulating and evaluating rations for dairy cows.

\section{ACKNOWLEDGMENTS}

Larry Douglass, University of Maryland, is acknowledged for his help with the statistical analysis of the $\mathrm{pH}$ data. Also, the authors would like to thank Jerry Gunther, Robert Elderbrook, and the rest of the staff at the Dairy Cattle Research Center for taking care of and feeding the cows.

\section{REFERENCES}

Allen, M. S. 1997. Relationship between fermentation acid production in the rumen and the requirement for physically effective fiber. J. Dairy Sci. 80:1447-1462. 
American National Standards Institute. 1988. Method for determining and expressing fineness of feed material by sieving. ASAE S424, ASAE, St. Joseph, MI.

Ash, R. W. 1959. Inhibition and excitation of reticulo-rumen contractions following the introduction of acids into the rumen and abomasum. J. Physiol. 147:58-73.

Bailey, C. B. 1961. Saliva secretion and its relation to feeding in cattle. 3 . The rate of secretion of mixed saliva in the cow during eating, with an estimate of the magnitude of the total daily secretion of mixed saliva. Br. J. Nutr. 15:443-451.

Bailey, C. B. and C. C. Balch. 1961a. Saliva secretion and its relation to feeding in cattle. 1 . The composition and rate of secretion of parotid saliva in a small steer. Br. J. Nutr. 15:371-382.

Bailey, C. B., and C. C. Balch. 1961b. Saliva secretion and its relation to feeding in cattle. 2. The composition and rate of secretion in the cow during rest. Br. J. Nutr. 15:383-402.

Beauchemin, K. A. 1991. Effects of dietary neutral detergent fiber concentration and alfalfa hay quality on chewing, rumen function, and milk production of dairy cows. J. Dairy Sci. 74:3140-3151.

Britton, R. A., and R. A. Stock. 1987. Acidosis, rate of starch digestion and intake. Okla. Agric. Exp. Stn. MP-121, 125-137.

Cassida, K. A., and M. R. Stokes. 1986. Eating and resting salivation in early lactation dairy cows. J. Dairy Sci. 69:1282-1292.

CPM Dairy. 1997. Beta version 1.1. The Center for Animal Health and Productivity, School of Veterinary Medicine, University of Pennsylvania.

Erdman, R. A. 1988. Dietary buffering requirements of the lactating dairy cow: A review. J. Dairy Sci. 71:3246-3266.

Grant, R. J., V. F. Colenbrander, and D. R. Mertens. 1990a. Milk fat depression in dairy cows: role of particle size of alfalfa hay. J. Dairy Sci. 73:1823-1833.

Grant, R. J., V. F. Colenbrander, and D. R. Mertens. 1990b. Milk fat depression in dairy cows: role of silage particle size. J. Dairy Sci. 73:1834-1842.

Hoover, W. H. 1986. Chemical factors involved in ruminal fiber digestion. J. Dairy Sci. 69:2755-2767.
Krause, K. M., D. K. Combs, and K. A. Beauchemin. 2002. Effects of forage, particle size, and grain fermentability in midlactaion cows. I. Milk production and diet digestibility. J. Dairy Sci. (submitted).

Mertens, D. R. 1997. Creating a system for meeting the fiber requirements of dairy cows. J. Dairy Sci. 80:1463-1481.

Mould, F. L., E. R. Ørskov, and S. O. Mann. 1983. Associative effects of mixed feeds. I. Effects of type and level of supplementation and the influence of the rumen fluid $\mathrm{pH}$ on cellolysis in vivo and dry matter digestion of various roughages. Anim. Feed Sci. Technol. 10:15-30.

Owens, F., D. Secrist, J. Hill, and D. Gill. 1996. Pages 1-16 in A new look at acidosis. in Proc. Southwest Nutrition Conf., Phoenix, AZ.

Pitt, R. E. , J. S. Van Kessel, D. G. Fox, A. N. Pell, M. C. Barry, and P. J. Van Soest. 1995. Prediction of ruminal volatile fatty acids and $\mathrm{pH}$ within the net carbohydrate and protein system. J. Anim. Sci. 74:226-244.

SAS User's Guide: Statistics, Version 7 Edition. 1998. SAS Inst., Inc., Cary, NC.

Slyter, L. L. 1976. Influence of acidosis on ruminal function. J. Anim. Sci. 43:910-929.

Sudweeks, E. M. 1977. Chewing time, rumen fermentation, and their relationship in steers as affected by diet composition. J. Anim. Sci. 44:694-701.

Sudweeks, E. M., L. O. Ely, D. R. Mertens, and L. R. Sisk. 1981 Assessing minimum amounts and form of roughages in ruminant diets: Roughage value index system. J. Anim. Sci. 53:1406-1411.

Wangsness, P. J., L. E. Chase, A. D. Peterson, T. G. Hartsock, D. J. Kellmel, and B. R. Baumgardt. 1976. System for monitoring feeding behavior of sheep. J. Anim. Sci. 42:1544-1549.

Woodford, J. A., N. A. Jorgensen, and G. P. Barrington. 1986. Impact of dietary fiber and physical form on performance of lactating dairy cows. J. Dairy Sci. 69:1035-1047.

Woodford, S. T., and M. R. Murphy. 1988. Effect of forage physical form on chewing activity, dry matter intake, and rumen function of dairy cows in early lactation. J. Dairy Sci. 71:674-686. 